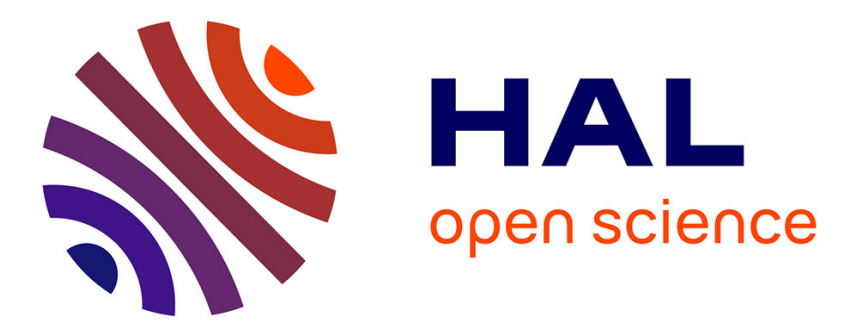

\title{
Microstructural effects in steel under the action of the quasispherically converging shock wave
}

\author{
B. Litvinov, V. Zel'Dovich, O. Rinkevich, V. Buzanov, N. Purygin
}

\section{To cite this version:}

B. Litvinov, V. Zel'Dovich, O. Rinkevich, V. Buzanov, N. Purygin. Microstructural effects in steel under the action of the quasispherically converging shock wave. Journal de Physique IV Proceedings, 1994, 04 (C8), pp.C8-399-C8-402. 10.1051/jp4:1994861 . jpa-00253421

\section{HAL Id: jpa-00253421 https://hal.science/jpa-00253421}

Submitted on 1 Jan 1994

HAL is a multi-disciplinary open access archive for the deposit and dissemination of scientific research documents, whether they are published or not. The documents may come from teaching and research institutions in France or abroad, or from public or private research centers.
L'archive ouverte pluridisciplinaire HAL, est destinée au dépôt et à la diffusion de documents scientifiques de niveau recherche, publiés ou non, émanant des établissements d'enseignement et de recherche français ou étrangers, des laboratoires publics ou privés. 


\title{
Microstructural effects in steel under the action of the quasispherically converging shock wave
}

\author{
B.V. Litvinov, V.I. Zel'dovich, O.S. Rinkevich, V.I. Buzanov and N.P. Purygin \\ Russian Federal Nuclear Centre, VNIITF, P.O. Box 245, Chelyabinsk-70, 454070, Russia
}

\begin{abstract}
Résumé: Nous avons étudié les changements structuraux provoqués dans des billes d'acier de 40 et $60 \mathrm{~mm}$ de diamètre, par l'explosion de charges sphériques ayant respectivement 20 et $10 \mathrm{~mm}$ d'épaisseur.

L'explosion a été initiée en 12 points situés de manière régulière sur la surface externe de la charge. La charge explosive était confinée par une lourde enveloppe afin de préserver l'échantillon. Dans la bille de $60 \mathrm{~mm}$ de diamètre, les changements structuraux sont principalement liés aux interactions des ondes de choc et aux phénomènes de déformations provoqués par ces dernières. Dans la bille de $40 \mathrm{~mm}$ de diamètre, l'intensité de l'onde de choc convergente est notablement plus élevée, ce qui fait que l'élévation de température joue un rôle important (fusion et cristallisation ultérieure, formation de phase gamma).
\end{abstract}

\begin{abstract}
Investigations were made into structural changes in steel and brass balls with diameters of 40 and $60 \mathrm{~mm}$ arising from the influence of the explosion of spherical charges with thickness of 20 and $10 \mathrm{~mm}$, respectively. The explosion was initiated at 12 points uniformly located on the external surface of the charge, which was surrounded by heavy casing to preserve the samples. In a ball sample $60 \mathrm{~mm}$ in diameter structural changes were conditioned mainly by shock wave interactions and the resulting deformation. In a sample $40 \mathrm{~mm}$ in diameter, where convergent shock wave intensity is notably higher, temperature increase plays an important role, resulting in melting and subsequent crystallization and phase information.
\end{abstract}

\section{EXPERIMENTAL METHODS}

Ball samples of steel and brass, 40 and $60 \mathrm{~mm}$ in diameter, were explosively loaded using spherical charges with thicknesses of 20 and $10 \mathrm{~mm}$, respectively. The explosion was initiated from the surface at 12 points uniformly located on the sphere. The charge of explosive was surrounded by a massive casing which preserved the integrity of the samples [1]. Under this type of loading the ball samples represented quasi-dodecahedrons, whose face centres coincide with the projection of the initiation points. On the surface of the balls, especially those of brass, lines of intersection of the detonation waves were observed, see fig. 1 . These lines form the correct geometric pattern. The lines of the first order are the edges of quasi-dodecahedrons while the lines of the second order connect the centres of the faces with the vertices of quasi-dodecahedrons. 


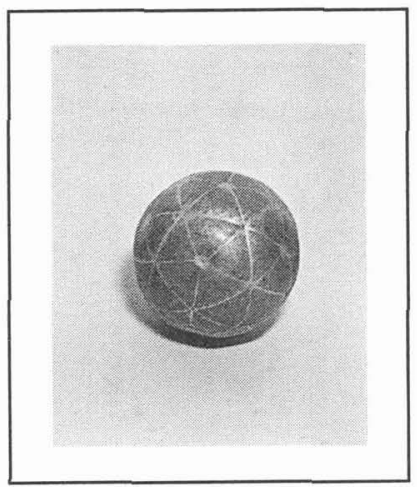

Fig. 1 View of the surface of a $40 \mathrm{~mm}$ diameter brass ball after explosive loading, showing a quasidodecahedron.

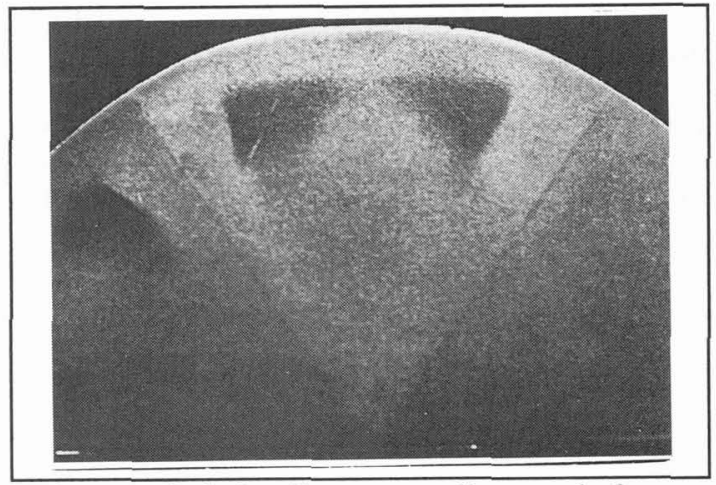

Fig. 2 Al'tshuler figures on diametral plane for $60 \mathrm{~mm}$ diameter steel ball

The calculation of the pressure distribution in the samples, taking into account the time difference between the arrival of detonation waves at the surface of the ball samples and shock wave interactions within the balls, represents a rather complicated problem. That is why the assessment of pressure in the balls was performed using a spherical symmetry approximation (one-dimensional movement). The pressure increases according to a $1 / \mathbf{r}^{\mathrm{n}}$ law, where $\mathbf{r}$ is the distance from the ball centre and $\mathbf{n}$ is equal to 0.9 .

After explosive loading the samples were cut into two parts to perform metallographic and electromicroscopic studies and measurements of microhardness. The diametral plane of cut ran through the centres of four faces of the quasi-dodecahedron, coinciding with the heights of the faces, and through two edges.

\section{RESULTS and DISCUSSION}

Chemical etching of a steel sample of $60 \mathrm{~mm}$ diameter revealed the interaction of spherically convergent shock waves. The main elements of this picture, see fig. 2 , are radial beams representing the section of pyramids whose bases are the faces of the quasi-dodecahedron. A similar picture of shock wave interaction was observed by L.V. Al'tshuler and his colleagues on cylindrical samples [2], and we propose to call such pictures of shock wave interaction - Al'tshuler figures. Microhardness measurements showed that the highest hardening of the steel (the steel contained 0.20 weight \% of C) is observed in the Al'tshuler figures. In addition to these radial beams, fig. 2 also shows approximately triangular regions between the radial beams as well as oval regions around pyramid heights and near surface layer of quasi-dodecahedron.

Metallographic and electro-microscopic studies showed that in Al'tshuler figures there are sections of strongly localized flow with vortexwise structures, see fig. 3. Pearlite colonies are stretched along the flow direction and plates of cementite and ferrite in pearlite are severely deformed. In the sections of triangular form and in the near surface layer residual ferrite undergoes sufficient deformation to give a laminated structure due to the cycle $\alpha \rightarrow \epsilon \rightarrow \alpha$ of transformation and twinning, see fig. 4. Retention of the initial pearlite structure, see figs. 3 and 4 , suggests that the pressure in the central part of the $60 \mathrm{~mm}$ diameter steel sample did not exceed $200 \mathrm{GPa}$; otherwise one can expect a pearlite transformation into austenite. 


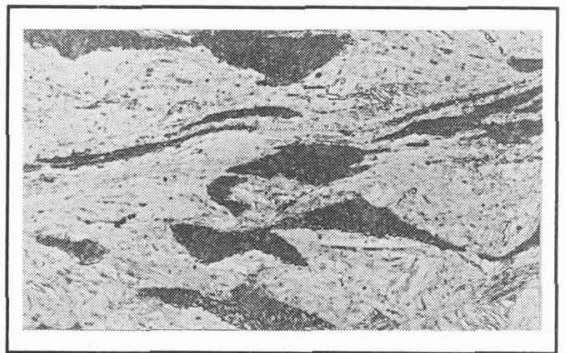

Fig. 3 Localized flow (longitudinal channel of deformation) in a $60 \mathrm{~mm}$ diameter ball (x350)

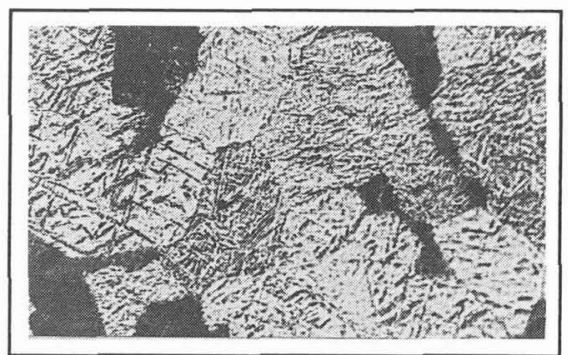

Fig. 4 Ferrite-pearlite structure in $60 \mathrm{~mm}$ diameter ball. Ferrite has laminar structure (x350)

Etching of the $40 \mathrm{~mm}$ diameter steel sample (the steel contained 0.37 weight $\%$ of $\mathrm{C}$ and 1.1 weight $\%$ of $\mathrm{Cr}$ ) revealed the approximately centro-symmetrical structure shown in fig. 5 . In the centre there is a spherical cavity with a diameter of about $5 \mathrm{~mm}$. Around it there is a narrow circular zone of pillar crystals having a distinct dendrite structure, see fig.6. The dendrite structure shows that under shock-wave loading melting and subsequent crystallization took place. Comparison with the critical pressure for the $\gamma \rightarrow \mathrm{L}$ transition in iron [3] suggests that the pressure in the narrow circular zone and the spherical cavity exceeded $243 \mathrm{GPa}$. The form of the dendrite structure indicates that melting and crystallization took place during unloading.

Around the zone of pillar crystals there is a circular zone of thickness from 2 to $2.5 \mathrm{~mm}$ in which the $\gamma$-phase formation occurred. According to [3,4] pressures in this zone could exceed $200 \mathrm{GPa}$. Microstructural studies showed that in the outer part of this zone $\gamma$-phase formation (i.e. austenite) occurred in the place of the pearlite component of the steel initial structure. Free ferrite did not convert into austenite though it could undergo $\alpha \rightarrow \epsilon$ transition. The inner part of the zone turned into austenite completely. Measurements of microhardness and metallographic studies showed that austenite formed under shock-wave loading turns into a needle-like structure, see fig.7, whose hardness is less than for a martensitic structure. This fact in comparison with TTT-diagrams for cooling of austenite in steels with a similar composition suggests that the cooling rate in the austenite region in the $40 \mathrm{~mm}$ diameter sample did not exceed $10^{3} \mathrm{~K} / \mathrm{s}$.

The outermost zone is $\sim 14 \mathrm{~mm}$ thick and occupies most of the sample. Here the initial ferritepearlite structure of the steel is preserved (fig. 5 shows this zone darker in comparison with the inner zone of the sample). On the boundaries of this and previous zones there is a region of radial cracks. In the outermost zone, often near the cracks, one can observe regions of strong localized flow, as

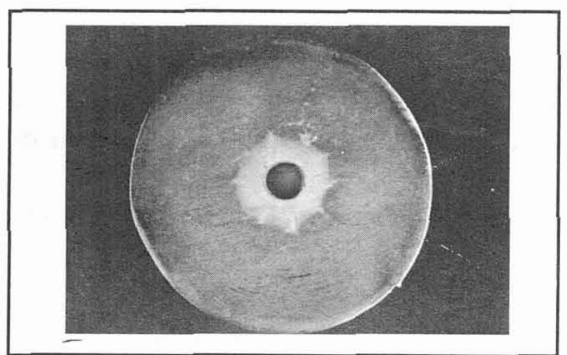

Fig. 5 View of the diametral plane for $40 \mathrm{~mm}$ diameter steel ball

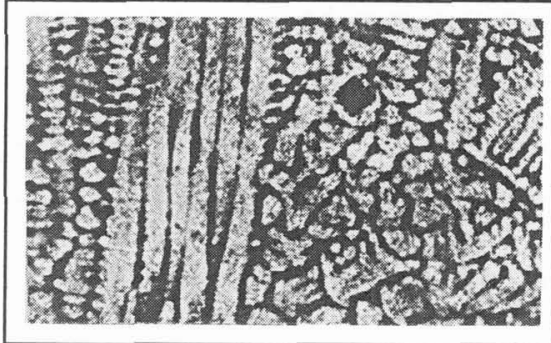

Fig. 6 Dendrite structure around the cavity in $40 \mathrm{~mm}$ diameter steel ball

(x350) 


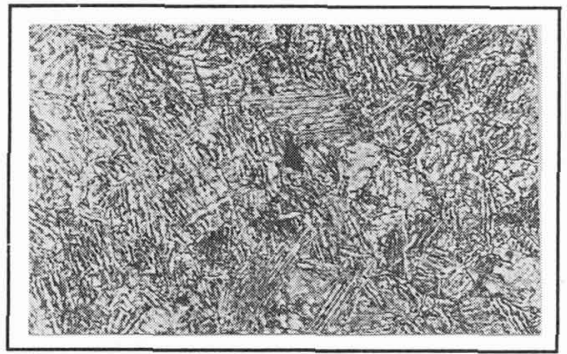

Fig. 7 Needlelike structure (bainite) in a $40 \mathrm{~mm}$ diameter ball (x350)

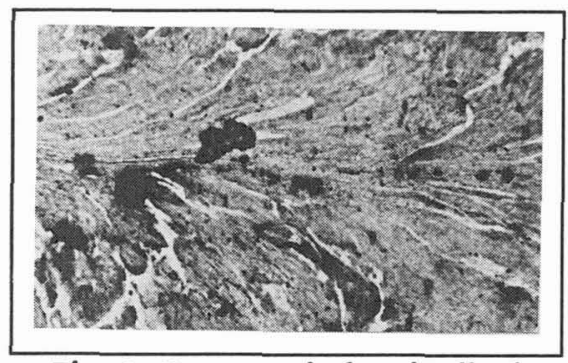

Fig. 8 Structure in longitudinal deformation channel, $40 \mathrm{~mm}$ diameter ball (x140)

shown in fig.3, which we call longitudinal channels of deformation. Metal flow in longitudinal channels runs in radial direction, along the direction of shock waves distribution. In longitudinal channels of deformation the steel structure has a distinct fibrous texture. The degree of deformation in them is approximately $80 \%$ by visual estimation of the structure. This relates to both the $60 \mathrm{~mm}$ diameter sample, see fig. 3 , and the $40 \mathrm{~mm}$ diameter sample, see fig. 8 .

\section{CONCLUSIONS}

In the $60 \mathrm{~mm}$ diameter ball sample structural changes are conditioned mainly by shock wave interactions and the deformation phenomena they cause, i.e. Al'tshuler figures and longitudinal channels of deformation. In the $40 \mathrm{~mm}$ diameter sample temperature increase plays the major role in structure formation, i.e. melting and subsequent crystallization and $\boldsymbol{\gamma}$-phase formation.

It is necessary to note that the formation of a cavity in spherical samples under the influence of spherical convergent shock waves was described by Bakhrah and co-authors [5]. Information on the change in the structure and microhardness along the radius in steel spheres was given in the work by Kozlov [4].

\section{ACKNOWLEDGEMENTS}

The present work was performed under the financial support of the Russian Fund of Fundamental Investigations (project code 93-02-2762).

\section{REFERENCES}

1. Buzanov V.I. and Puryqin N.P., "Metal balls deformation under quasi-spherical loading", $\underline{X}$ Symposium on Combustion and Explosion, Chernogolovka, September 1992 (col. Detonation, Chernogolovka, 1992) pp. 131-132.

2. Al'tshuler L.V., Tarasov D.M., and Speranskaya M.P., Physics of Metals and Metal Study 13, \#5 (1962) 738-743.

3. Brown J.M. and McQueen R.G., J.Geophys.Res. 91, \#B7 (1986) 7485-7494.

4. Kozlov E.A., High Pressure Res. 10 (1992) 541-582.

5. Bakhrah S.M., Kovalev N.P., Nadykto B.A., Novikov S.A. and Chernyshow A.K., Doklady Akad. Nauk SSSR (DAN) 215, \#5 (1974) 1090. 